\title{
Evaluation of anti-inflammatory activities of ethanolic extract of Annona muricata leaves
}

\author{
Chan Pit Foong, Roslida Abdul Hamid
}

Department of Biomedical Sciences, Faculty of Medicine \& Health Sciences, Universiti Putra Malaysia, Malaysia.

\author{
Universiti Putra Malaysia, Malaysia.
}

\begin{abstract}
Traditionally, the leaves of Annona muricata L., Annonaceae, are used to treat headaches, fever, toothache, cough and asthma. The decoction of the leaves has parasiticide, antirheumatic and antineuralgic effects when used internally, while the cooked leaves, applied topically, fight rheumatism and abscesses. The aim of this study was to investigate acute and chronic anti-inflammatory potential of an ethanolic leaf extract of $A$. muricata (AML) in animal models. The ethanolic extract of A. muricata leaf extract was prepared and administered orally to experimental animals used. The anti-inflammatory activity was determined by xylene-induced ear edema in mice and Complete Freund's adjuvant (CFA)-induced arthritis in rats. The results demonstrated that AML is effective for both acute and chronic inflammation. It also significantly attenuated both TNF- $\alpha$ and IL- $1 \beta$ levels in CFAinduced arthritis model. Thus, these results have suggested that AML possesses both anti-inflammatory and anti-arthritic activities. The findings also suggest that AML presents notable anti-arthritic activity that may be mediated by suppressing proinflammatory cytokines.
\end{abstract}

Article

Received 20 Apr 2012

Accepted 23 May 2012

Available online 16 Aug 2012

Keywords:

Annona muricata anti-inflammatory anti-arthritic

CFA-induced arthritis xylene-induced oedema

ISSN 0102-695X http://dx.doi.org/10.1590/S0102695X2012005000096

\section{Introduction}

Rheumatoid arthritis is a chronic progressive autoimmune disorder pathologically characterized by synovial hyperplasia, inflammatory cell infiltration and angiogenesis (Rajkapoor et al., 2007). Conventional medicine, which including treatment with steroids, NonSteroidalAnti-Inflammatory Drugs (NSAID) and biological agents for example tumour necrosis factor alpha (TNF- $\alpha$ ) and interleukin-1 beta (IL-1 $\beta$ ) antagonists has limited ability against all forms of arthritis and are associated with various unpleasant side effects (Chandrashekaran et al., 2002). Therefore, a variety of herbal medicines developed from plant extracts are being used in the treatment of a wide variety of clinical diseases, through relatively little knowledge about their mechanisms of action is known (Ratheesh \& Helen, 2007). Research and developmental work in herbal medicine is essential because of its social and economic benefits it has become persistent part of present day healthcare in developing countries (Ighodaro et al., 2010).

Annona muricata L. (AML), family Annonaceae has many common names used by different countries' people. It is more known as soursop, guanabana, nangka blanda, pickly custard apple or durien belanda. In Malaysia, it is one of the popular striking fruits and has its potential for the soft drink industry. The ethnobotanical uses of soursop in Malaysia, including astringent and remedy for boil, cough, diarrhea, dermatosis, hypertension, rheumatism and styptic (Mat Salleh \& Ahmad, 1989).

Among the chemical constituents found in the leaf of A. muricata are alkaloids (Le Bouef et al., 1981; 1982), essential oils (Pélissler et al., 1994; Kossouh et al., 2007) and acetogenins (Wu et al., 1995a,b,c,d; Zeng et al., 1996; Kim et al., 1998a,b; Chang et al., 2003). In addition, A. muricata leaf extracts have antioxidant (Baskar et al., 2007) and molluscicidal properties (Santos \& Sant'Ana, 2001; Luna et al., 2006). Although there are a few studies have been reported on the anti-inflammatory actions of the plant's leaves (Roslida et al., 2010; De Sousa et al., 2010), but none of them has yet reported the effect of the plant's leaves in the chronic inflammation. Various non-steroidal anti-inflammatory drugs (NSAID) are widely used clinically for inflammatory diseases as well as rheumatoid arthritis. However, despite their great number, their therapeutic efficacy seems to be hampered by the presence of a number of undesired, and often serious, side effects. It would, therefore, be highly desirable to find less toxic alternatives, and some medicinal botanicals might be candidates for such alternatives. Therefore, in the present study, we investigated the possible anti-inflammatory effect of ethanolic extract from the leaves of AML in acute and 
chronic inflammation by using different animal models from the reported studies.

\section{Materials and Methods}

\section{Plant material}

About $2.2 \mathrm{~kg}$ of fresh leaves of Annona muricata L., Annonaceae, were obtained from Raub, Pahang, Malaysia in December 2007. A voucher specimen (number FRI 57966) has been deposited in the herbarium of Forest Research Institute Malaysia, Kepong, Selangor, Malaysia. The grounded leaf of $A$. muricata $(1.5 \mathrm{~kg})$ was extracted with $80 \%$ aqueous ethanol by cold maceration for two days. The extract was concentrated in a rotary evaporator at a reduced pressure to yield $158.18 \mathrm{~g}(10.55 \%$, w/w) of crude ethanolic extract. The crude extract was weighed and dissolved with $1 \%$ Tween 80 at the desired dose for pharmacological testing.

\section{Phytochemical analysis}

The extract was subjected to phytochemical analysis for identification of alkaloid, saponin, tannins, flavonoids, triterpenes and steroid detection using conventional protocol (Evans, 1989).

\section{Animals}

Experiments were conducted using healthy Sprague dawley rats of either sex weighing between 170$250 \mathrm{~g}$ and adult ICR strain mice of either sex (20-30 g). Animals were obtained from Animal Unit of Faculty of Medicine \& Health Sciences, Universiti Putra Malaysia with ethics approval from the Animal Ethics Committee of Universiti Putra Malaysia (UPM/FPSK/PADS/ BR.UUH/00267). The animals were housed in a group of six in the standard cages at room temperature $\left(25 \pm 3^{\circ} \mathrm{C}\right)$ in $12 \mathrm{~h}$ dark and $12 \mathrm{~h}$ light cycles with both food and water ad libitum $24 \mathrm{~h}$ before the experiment. All animals were acclimatized in the Animal House of Faculty of Medicine and Health Sciences for at least one week before used.

\section{Drugs}

Indomethacin was obtained from Sigma Chemical Co. (St. Louis, MO, U.S.A). Tween 80 was obtained from Fluka BioChemika, Sigma-Aldrich. Xylene was obtained from BDH Chemicals, UK, while complete Freund's adjuvant was obtained from Sigma Chemical Co, USA. The kits for IL- $1 \beta$ and TNF- $\alpha$ ELISA were purchased from USA Pierce Biotechnology, Inc.

\section{Anti-inflammatory activity}

Adjuvant-induced arthritis assessments in rats

Rats were induced with arthritis by intradermal injections of $100 \mu \mathrm{L}$ of Freund's complete adjuvant containing $10 \mathrm{mg}$ heat-killed Mycobacterium tuberculosis in mineral oil $(5 \mathrm{mg} / \mathrm{mL})$ into the right foot paw of the rats on day 0 (Newbould, 1963). The treated groups with tested drug and extract were administered orally on the next day onwards at the doses of 10, 30, 100 and $300 \mathrm{mg} / \mathrm{kg}$ up to fifteen days. The reference group received indomethacin (10 $\mathrm{mg} / \mathrm{kg}$, p.o.). During treatment, paw volume was assessed every other day with a plethysmometer (IITC Inc., Woodland Hills, CA). This was a device consists of two vertical, interconnected, water-filled Perspex cells. The water level in the smaller cell, which contains a transducer will rise when the paw that to be measured was dipped into the larger cell to the ankle line. The transducer converts detected paw volume into milliliters, then the exact volume was measured electronically on a monitor. The volume was performed blinded by the investigators to the treatment group to avoid bias.

\section{Local tissue collection and ELISA}

After arthritis assessment on day 15 postinjection, the animals were fasted overnight and then deeply anesthetized under ether anesthesia. The ankle tissue was collected, frozen, weighed and immediately placed in 0.50 $\mathrm{mL}$ of ice-cold homogenization buffer $(50 \mathrm{mmol} / \mathrm{L} \mathrm{NaCl}$, $10 \mathrm{mmol} / \mathrm{L}$ Tris, $2.5 \mathrm{mmol} / \mathrm{L} \mathrm{MgCl}$, $\mathrm{pH} 7.4$ ), to $50 \mathrm{~mL}$ of which the complete protease inhibitor tablet (Boehringer Mannheim, Germany) was added. The tissues were then homogenized using an ultra-sonic tissue homogenizer. The homogenate tissues were spun at $20000 \mathrm{x} \mathrm{g}$ for $30 \mathrm{~min}$ at 4 ${ }^{\circ} \mathrm{C}$, and the supernatant was collected and stored at $-80^{\circ} \mathrm{C}$. The animals were euthanized after the tissue collection.

IL-1 $\beta$ and TNF- $\alpha$ level of the local tissue homogenate supernatant were determined using enzymelinked immunosorbent assay (ELISA) kits according to the procedures recommended by the manufacturer. The IL-1 $\beta$ protein was quantified by comparing the sample to the standard curve generated from the kit. The same procedure was applied to assay TNF- $\alpha$ with the substitution of antibodies specific to that cytokine.

\section{Xylene-induced ear edema}

Mice were allotted into groups of 6 animals each. After $1 \mathrm{~h}$ of oral treatment of mice with $1 \%$ Tween $80(10 \mathrm{~mL} / \mathrm{kg})$, indomethacin $(20 \mathrm{mg} / \mathrm{kg})$ and extract (10-300 $\mathrm{mg} / \mathrm{kg})$, edema was induced in each mouse by applying xylene $(0.03 \mathrm{~mL})$ to the anterior and posterior surfaces of the right ear. Mice were sacrificed under 
ether anesthesia $2 \mathrm{~h}$ after xylene application and both ears were removed. Circular sections of both treated and untreated ears were taken using a $7 \mathrm{~mm}$ diameter cork borer and weighed. The mean of the difference between the right treated ear section and left untreated ear section was determined for each group (Tang et al., 1984).

\section{Statistical analysis}

The values of statistical analysis were expressed as mean values \pm SEM. The results of the experiment were performed as changes of percentage from control value. Data was analyzed by ANOVA followed by Dunnett's multiple comparison tests. $p \leq 0.05$ was considered to be statistical significance.

\section{Results}

\section{Phytochemical screening}

Phytochemical screening of the AML leaves extract discovered the presence of various constituents (alkaloids, saponins, flavonoids, tannins, triterpenes or steroids).

\section{Anti-inflammatory activity}

Effects of AML on arthritic paw edema

The present study (Figure 1) elicited that the time course of edema and inhibition rate after administration of CFA and AML extract. Edema value of the injected footpad increased and reached a peak at day 15 . The extract had mild anti-inflammatory effect at dose $3 \mathrm{mg} / \mathrm{kg}$. However, administration of AML at the highest dose 100 $\mathrm{mg} / \mathrm{kg}$ significantly $(p<0.05)$ attenuated the development of the swelling induced by CFA. The dose of $100 \mathrm{mg} /$ $\mathrm{kg}$ demonstrated anti-inflammatory property, which was upheld until the experiment was terminated on day 15 . The anti-inflammatory activity of AML at dose 30 and $100 \mathrm{mg} /$ $\mathrm{kg}$ was comparable to indomethacin (Table 1).

AML effects on local arthritic tissue cytokines

In Figure 2, AML at $30 \mathrm{mg} / \mathrm{kg}$ significantly suppressed IL-1 $\beta$ levels $(702.4 \pm 36.99 \mathrm{pg} / \mathrm{mg}$ protein, $p<0.05)$ compared to the vehicle control arthritic rats $(1139 \pm 174.9 \mathrm{pg} / \mathrm{mg}$ protein). AML at $100 \mathrm{mg} / \mathrm{kg}$ significantly decreased IL-1 $\beta$ levels $(648.6 \pm 35.11 \mathrm{pg} / \mathrm{mg}$ protein, $p<0.01)$ and the inhibitory effect was greater than indomethacin $(664.4 \pm 87.67 \mathrm{pg} / \mathrm{mg}$ protein, $p<0.05)$ on day 15 post-CFA injection.

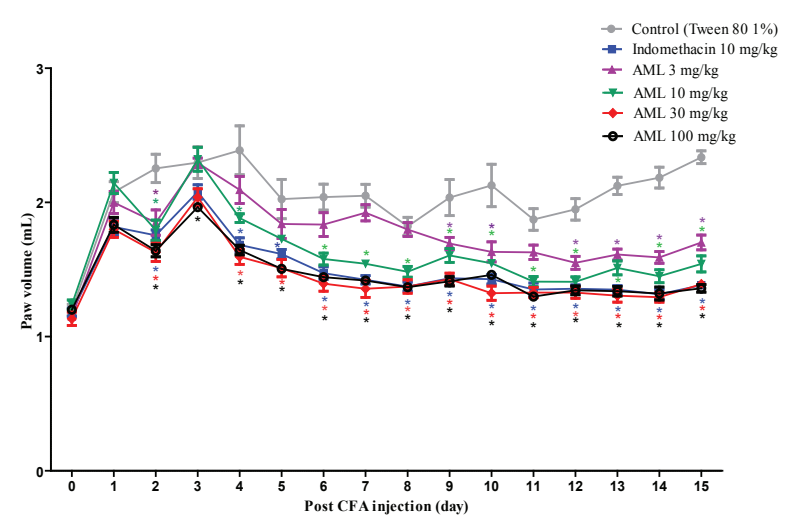

Figure 1. Effect of AML on arthritis assessed with paw volume (mean \pm S.E.M.) in rats. ${ }^{*} p<0.05$ compared to vehicle control, at the same time point.

On day 15 post-CFA injection, AML dosagedependently attenuated TNF- $\alpha$ in local arthritic tissue by one-thirds in the $30 \mathrm{mg} / \mathrm{kg}$ group $(281 \pm 17.08 \mathrm{pg} / \mathrm{mg}$ protein, $p<0.05)$ and by half in the $100 \mathrm{mg} / \mathrm{kg}$ group $(242.9 \pm 51.4$ $\mathrm{pg} / \mathrm{mg}$ protein, $p<0.01)$ compared to the vehicle control arthritic group (444.6 $\pm 35.35 \mathrm{pg} / \mathrm{mg}$ protein). The extract's inhibitory effect at the highest dose was greater than the indomethacin $(278.9 \pm 11.25 \mathrm{pg} / \mathrm{mg}$ protein, $p<0.05)$ (Figure 3).

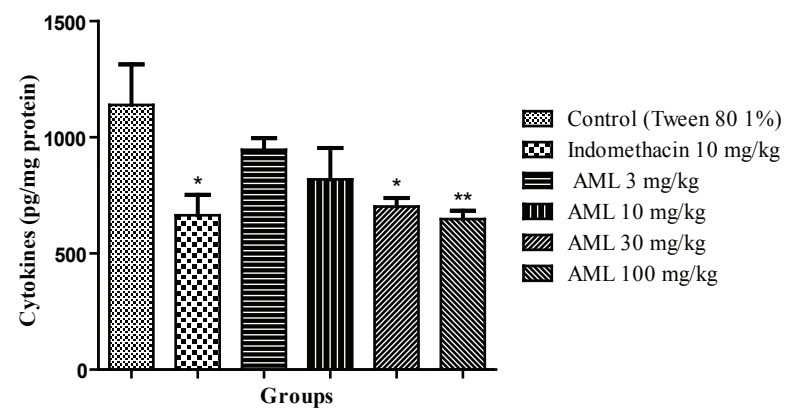

Figure 2. Effect of AML on IL-1 $\beta$ level ( $\mathrm{pg} / \mathrm{mg}$ protein, mean $\pm \mathrm{SEM})$ fifteen days post-CFA injection. ${ }^{*} p<0.05$ and $* * p<0.01$, compared to the vehicle control.

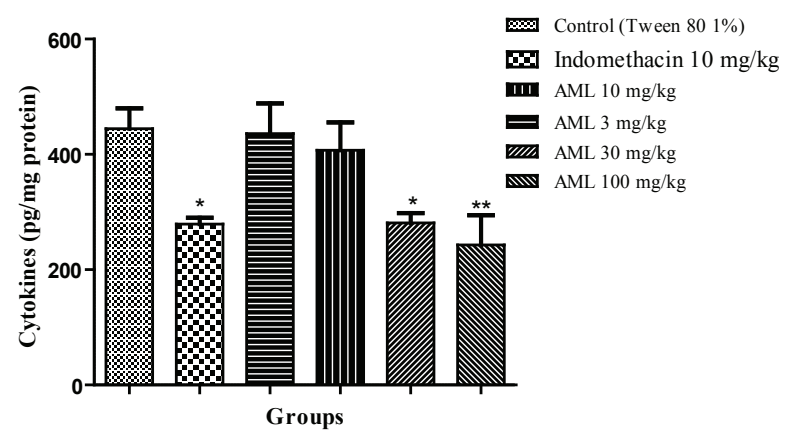

Figure 3. Effect of AML on TNF- $\alpha$ level (pg/mg protein, mean $\pm \mathrm{SEM}$ ) fifteen days post-CFA injection. ${ }^{*} p<0.05$ and $*_{*} p<0.01$, compared to the vehicle control. 
Table 1. Effect of AML on Complete Freund's Adjuvant induced paw edema in rats.

\begin{tabular}{lccccc}
\hline \multirow{2}{*}{ Drug treatments } & Dose $(\mathrm{mg} / \mathrm{kg})$ & \multicolumn{4}{c}{ Paw volume $(\mathrm{mL})$} \\
\cline { 3 - 6 } & & $3^{\text {rd }}$ day & $5^{\text {th }}$ day & \multicolumn{1}{c}{$10^{\text {th }}$ day } & $15^{\text {th }}$ day \\
\hline Control & $10 \mathrm{~mL} / \mathrm{kg}$ & $1.10 \pm 0.14$ & $0.83 \pm 0.18$ & $0.93 \pm 0.18$ & $1.14 \pm 0.06$ \\
AML & 3 & $1.14 \pm 0.04$ & $0.69 \pm 0.12$ & $0.48 \pm 0.08^{*}$ & $0.54 \pm 0.07^{*}$ \\
& 10 & $1.08 \pm 0.07$ & $0.49 \pm 0.03$ & $0.31 \pm 0.02^{*}$ & $0.30 \pm 0.06^{*}$ \\
& 30 & $0.91 \pm 0.10$ & $0.38 \pm 0.07^{*}$ & $0.19 \pm 0.07^{*}$ & $0.26 \pm 0.04^{*}$ \\
Indomethacin & 100 & $0.77 \pm 0.04^{*}$ & $0.31 \pm 0.04^{*}$ & $0.26 \pm 0.04^{*}$ & $0.16 \pm 0.03^{*}$ \\
\hline
\end{tabular}

Data is expressed as mean \pm SEM of six animals. ${ }^{*} p<0.05$ indicates significant difference when compared with control by using ANOVA followed by Dunnett's Test.

Table 2. Effect of Annona muricata leaves extract on xylene-induced ear edema.

\begin{tabular}{lccccc}
\hline \multicolumn{1}{c}{ Groups } & Dose $(\mathrm{mg} / \mathrm{kg})$ & Weight of right ear $(\mathrm{mg})$ & Weight of left ear $(\mathrm{mg})$ & Difference $(\mathrm{mg})$ & Inhibition $(\%)$ \\
\hline Control & $10 \mathrm{~mL} / \mathrm{kg}$ & $17.42 \pm 0.69$ & $11.53 \pm 0.28$ & $5.88 \pm 0.89$ & - \\
AML & 10 & $16.10 \pm 0.67$ & $11.25 \pm 0.77$ & $4.85 \pm 1.08$ & 17.52 \\
& 30 & $17.23 \pm 1.18$ & $13.67 \pm 0.64$ & $3.55 \pm 1.16$ & 39.63 \\
& 100 & $14.93 \pm 0.72$ & $12.77 \pm 0.26$ & $2.17 \pm 1.42 *$ & 63.10 \\
Indomethacin & 300 & $14.02 \pm 0.73$ & $12.47 \pm 0.51$ & $1.55 \pm 0.71 * *$ & 72.41 \\
\hline
\end{tabular}

Data are expressed as mean \pm SEM of six mice. ${ }^{*} p<0.05, * * p<0.01$ indicates significant difference when compare with control by using ANOVA followed by Dunnett's Test.

Effect of AML on xylene-induced ear oedema

Oral administration of the ethanolic extract of A. muricata (Annonaceae) (10-300 mg/kg), $1 \mathrm{~h}$ before topical application of xylene, inhibited the development of ear edema in a dose dependently manner. The dose of 100 and $300 \mathrm{mg} / \mathrm{kg}$ significantly $(p<0.05)$ reduced the weight of xylene-induced ear edema in mice with an inhibitory effect of 63.10 and $72.41 \%$, respectively while the smaller dose produced no significant effect. The inhibition produced by both 100 and $300 \mathrm{mg} / \mathrm{kg}$ of the extract were greater than that produced by $20 \mathrm{mg} /$ $\mathrm{kg}$ of indomethacin $(55.44 \%)$ (Table 2).

\section{Discussion}

The efficacies of herbal medicines have been studied in many previous cases, including acute and chronic inflammatory as well as arthritic illnesses (Ahmed et al., 2005). In this study, experimental results show that the ethanolic extract of AML performs as an anti-inflammatory agent in mice and rats in both acute and chronic inflammation models. Priorly, AML has been reported on its anti-inflammatory and antinociceptive effects on different animal models (De Sousa et al., 2010; Roslida et al., 2010; 2012). Thus, the current findings have strongly supported the claim that AML possesses anti-inflammatory effect as well as anti-arthritic activity based on the data from the current results. Furthermore, AML administered topically has also been observed to show similar activity when compared with the previous studies which were administered orally (Roslida et al., 2010)

Basically, there are many reports on studies of Annona muricata L., Annonaceae, in general but only a few on its isolated acetogenins especially acetogenins in the leaves of the plant. A screening program by NCI reported that A. muricata leaves extract showed active toxicity against cancer cells and researchers have been following up on these findings ever since (Tormo et al., 2003). Priorly, acetogenins isolated from A. muricata leaves such as annonacin has been reported to cause significant cell death in various cancer cell lines including skin cancer cell lines (Yuan et al., 2003), whilst muricatocin A and annomuricin A has significantly enhanced cytotoxicity against the A-549 human lung tumor cell line (Wu et al., 1995a; 1995b; 1995c). Furthermore, annonacin was also reported to be highly toxic to ovarian, cervical, breast, bladder and skin cancer cell lines at very low dosages (Yuan et al., 2003) and also acts as mitochondrial complex I inhibitor (Gonzalez-Coloma et al., 2002).

Xylene-induced ear oedema test substitutes a skin inflammation model appropriate for the experimental of topical anti-inflammatory agent. Ear oedema model allows the evaluation of antiinflammatory steroids and is less sensitive to nonsteroidal anti-inflammatory agents (Zaninir et al., 1992). Xylene-induced mouse ear oedema also reflects 
the oedematization during the early stages of acute inflammation, which was probably related with the release and inhibition of the inflammation factors (Lin et al., 2007). Histopathologically, severe vasodilation, oedematous changes of the skin and infiltration of inflammatory cells are detected as signs of acute inflammation after topical application of xylene (Kou et al., 2003). In the present study, the increases in ear weight were inhibited significantly by a doserelated manner in the higher doses of the extract; which indicates possible anti-phlogistic but not antiproliferative effects of the extract (Atta \& Alkofahi, 1998). The effect of AML extract in this model may also suggest inhibition of phospholipase $A_{2}$ (PLA2) (Akindele \& Adeyemi, 2007).

Rheumatoid arthritis (RA), defined as a symmetric polyarticular arthritis that basically affects small diarthroidal joints of the hands and feet, is the most common inflammatory arthritis as well as a major cause of disability (Firestein, 2003). The model of adjuvant induced arthritis in rats has been extensively used in the study of inflammatory processes (Jones \& Ward, 1966) and validated as a model of chronic pain (Colpaert et al., 1982). Rats were selected to induce arthritis because they develop a chronic swelling in multiple joints due to accumulation of inflammatory cells, erosion of joint cartilage and bone destruction. Furthermore, it also has close similarities to human rheumatoid diseases (Singh \& Majumdar, 1996). The determination of paw swelling is an apparently simple, sensitive and quick procedure for evaluating the degree of inflammation and the therapeutic effects of drugs (Tripathy et al., 2009).

CFA-induced polyarthritis is associated with an immune-mediated inflammatory reaction, and the rat is unique in developing polyarthritis after CFA treatment (Cai et al., 2006). The initial reaction of edema and softtissue thickening at the depot site in this model is caused by the irritant effect of the adjuvant, whereas the latephase arthritis and flare in the injected foot are presumed to be immunologic events (Ward \& Cloud, 1965). The appearance of secondary lesions, i.e. non-injected paw swelling is a manifestation of cell-mediated immunity. The suppression of such secondary lesions by a drug shows its immunosuppressive activity (Singh et al., 2003; Bani et al., 2007). The arthritis-like symptoms in adjuvant induced rats share several histopathological features with human RA, such as mononuclear cell infiltration and synoviocyte hyperplasia that results in pannus formation followed by bone and cartilage destruction (Bendele et al., 1999).

Paw swelling is one of the major factors in evaluating the degree of inflammation and therapeutic efficacy of the drugs (Begum \& Sadique, 1988). The initial inflammatory response is developed within hours, but more critical clinical signs observed from the $10^{\text {th }}$ post-inoculation day and thereafter and the changes remain detectable for several weeks (Colpaert et al., 1982). The present study demonstrated that AML extract is able to suppress the swelling of the paws in both acute and chronic phases. This maybe due to the suppression of the inflammatory mediator released due to the induction of CFA (Tripathy et al., 2009)

Further, we found that at the higher dosage i.e 30 and $100 \mathrm{mg} / \mathrm{kg}$, AML extract significantly decreased the concentration of the pro-inflammatory cytokines TNF- $\alpha$ and IL- $1 \beta$ at the local inflammation site in the AA. It was reported that increased expression of inflammatory cytokines, including TNF- $\alpha$ and IL- $1 \beta$ was observed in the bone region of the knee joint or serum samples from human osteoarthritis or rheumatoid arthritis patients (Kaneko et al., 2001). TNF- $\alpha$ and IL- $1 \beta$ enhance the proliferation of fibroblasts, stimulate the production of $\mathrm{PGE}_{2}$ (Arend \& Dayer, 1995), and increase the expression of other cytokines and synthesis of collagen by synovial cells, contributing to cartilage and bone destruction (Dayer \& Fenner, 1992). Thus, various strategies to block their activity are now being clinically applied and have been shown to be effective in the treatment of experimental arthritis (Moreland et al., 1999). In the present study, the anti-inflammatory action of AML extract is associated with significantly reduced TNF- $\alpha$ and IL- $1 \beta$ levels in the sera of AA.

Phytochemical screening done on the ethanolic extract of AML indicated that it contains alkaloids, saponins, flavonoids, tannins, triterpenes and steroid. Flavonoids and tannins have been reported to inhibit prostaglandin synthesis (Alcaraz \& Ferrandiz, 1987). It is ubiquitously known that flavonoids have a great potential as anti-inflammatory agents (Tapas et al., 2008; Tuñón et al., 2009; Serafini et al., 2010). Therefore, we postulated that flavonoids in the extract may correlate appropriately for the present activities. The presence of other constituents in the extract such as tannins may give the synergistic effect to the flavonoids.

In summary, the present study indicates that the ethanolic extract of AML has the potential of becoming an inflammatory agent as it has been shown to be effective for acute inflammation (xylene-induced ear edema) and chronic inflammation (CFA-induced arthritis) in a dose dependent manner. The study also indicates that AML is able to produce anti-arthritic effects in AA model by significantly suppressing pro-inflammatory cytokines such as TNF- $\alpha$ and IL-1 $\beta$. This suggests that, AML may be beneficial as an adjuvant to conventional drugs in the treatment of arthritis and related inflammatory.

\section{Acknowledgment}

The authors wish to thank the Faculty of Medicine 
\& Health Sciences, Universiti Putra Malaysia for the facilities and funding (Project no: 04/01/07/1019RU) provided for the study.

\section{References}

Ahmed S, Anuntiyo J, Malemud CJ, Haqqi TM 2005. Biological basis for the use of botanicals in osteoarthritis and rheumatoid arthritis: a review. Evid-Based Compl Alt 2: 301-308.

Akindele AJ, Adeyemi OO 2007. Anti-inflammatory activity of the aqueous leaf extracts of Byrsocarpus coccineus. Fitoterapia 78: 25-28.

Alcaraz MJ, Ferrandiz ML 1987. Modification of arachidonic metabolism by flavonoids. J Ethnopharmacol 21: 209-229.

Arend WP, Dayer JM 1995. Inhibition of the production and effects of interleukin-1 and tumor necrosis factor-a in rheumatoid arthritis. Arthritis Rheum 38: 151-160

Atta AH, Alkofahi A 1998. Antinociceptive and antiinflammatory effects of some Jordanian medicinal plants. J Ethnopharmacol 60: 117-124.

Bani S, Kaul A, Khan B, Gupta VK, Satti NK, Suri KA 2007. Anti-arthritic activity of a biopolymeric fraction from Euphorbia tirucalli. J Ethnopharmacol 110: 92-98.

Baskar R, Rajeswari V, Kumar TS 2007. In vitro antioxidant studies in leaves of Annona species. Indian J Exp Biol 45: 480-485.

Begum VH, Sadique J 1988. Long term effect of herbal drug Withania somnifera on adjuvant induced arthritis in rats. Indian J Exp. Biol 26: 877-882.

Bendele A, McComb J, Gould T, McAbee T, Sennello G, Chlipala E, Guy M 1999. Animal models of arthritis: relevance to human disease. Toxicol Pathol 27: 134142.

Cai X, Wong YF, Zhou H, Xie Y, Liu ZQ, Jiang ZH, Bian ZX, Xu H, Liu L 2006. The comparative study of SpragueDawley and Lewis rats in adjuvant induced arthritis. N-S Arch Pharmacol 373: 140-147.

Chandrasekaran S, Anilkumar S, Jamuna S 2002. Complementary and alternative drug therapy in arthritis. J Assoc Physician I 50: 225-227.

Chang FR, Liaw CC, Lin CY, Chou CJ, Chiu HF, Wu YC 2003. New adjacent bis-tetrahydrofuran Annonaceous acetogenins from Annona muricata. Planta Med 69: 241246.

Colpaert FC, Meert T, Witte P, Schmitt P 1982. Further evidence validating adjuvant arthritis as an experimental model of chronic pain in the rat. Life Sci 31: 67-75.

Dayer JM, Fenner H 1992 The role of cytokines and their inhibitors in arthritis. Bailliere Clin Rheum 6: 485-516.

De Sousa OV, Vieira GD-V, de Pinho JJRG, Yamamoto CH, Alves MS 2010. Antinociceptive and anti-inflammatory activities of the ethanol extract of Annona muricata L leaves in animal models. Int J Mol Sci 11: 2067-2078.
Evans WC 1989. Trease \& Evan's Pharmacognosy. $13^{\text {th }}$ ed. Balliere Tindal, London 419-420.

Firestein GS 2003. Evolving concepts of rheumatoid arthritis. Nature 423: 356-361

Gonzalez-Coloma A, Guadanoa A, Inesa C, Martınez-Diazb R, Cortesc D 2002. Selective action of acetogenin mitochondrial complex I inhibitors. Z Naturforsch 57c: 1028-1034.

Ighodaro I, Fidelis PC, Aigbe E 2010. Anti-inflammatory activity of aqueous fruit pulp extract of Hunteria umbellate K. Schum in acute and chronic inflammation. Acta Pol Pharm 67: 81-85.

Jones RS, Ward JW 1966. Adjuvant-induced polyarthritis in rats. In: (Bajusz E and Jasmin G. (Eds.), Methods and Achievements in Experimental Pathology. Basel/New York: S. Karger p. 607-638.

Kaneko M, Tomita T, Nakase T, Ohsawa Y, Seki H, Takeuchi E, Takano H, Shi K, Takahi K, Kominami E, Uchiyama Y, Yoshikawa H, Ochi T 2001. Expression of proteinases and inflammatory cytokines in subchondral bone region in the destructive joint in rheumatoid arthritis. Rheumatology 40: 247-255

Kim GS, Zeng L, Alali F, Rogers LL, Wu FE, McLaughlin JL, Sastrodihardjo S 1998a. Two new monotetrahydrofuran ring acetogenins, annomuricin $\mathrm{E}$ and muricapentocin, from the leaves of Annona muricata. J Nat Prod 61: 432-436.

Kim GS, Zeng L, Alali F, Rogers LL, Wu FE, Sastrodihardjo S, McLaughlin JL 1998b. Muricoreacin and murihexocin C, mono-tetrahydrofuran acetogenins, from the leaves of Annona muricata. Phytochemistry 49: 565-571.

Kossouoh C, Moudachirou M, Adjakidje V, Chalchat JC, Figuérédo G 2007. Essential oil chemical composition of Annona muricata L. leaves from Benin. J Essent Oil Res 19: 307-309.

Kou J, Ma R, Zhu D, Yan Y 2003. Blood-activating and antiinflammatory actions of Polygala fallax. Zhong Yao Cai 26: 268-271.

Leboeuf M, Legueut C, Cavé A, Desconclois JF, Forgacs P, Jacquemin H 1981. Alkaloids of Annonaceae. XXIX. Alkaloids of Annona muricata. Planta Med 42: 37-44.

Leboeuf M, Cavé A, Bhaumik PK, Mukherjee B, Mukherjee R 1982. The phytochemistry of the Annonaceae. Phytochemistry 21: 2783-2813.

Lin S, Zhang H, Han T, Wu JZ, Rahman K, Qin LP 2007. In vivo efect of casticin on acute inflammation. J Chinese Integr Med 5: 573-576.

Luna JDS, De Carvalho JM, De Lima MRF, Bieber LW, Bento ES, Franck X, Sant'ana AEG 2006. Acetogenins in Annona muricata L. (Annonaceae) leaves are potent molluscicides. Nat Prod Res 20: 253-257.

Mat Salleh K, Ahmad F 1989.The distribution of alkaloids, flavonoids in other active constituents in Malaysian Annonaceae. In Said IM, Din L. (Eds). Systematic identification of Natural Products, Kuala Lumpur, 
UNESCO. p. 65-92.

Moreland LW, Schiff MH, Baumgartner SW, Tindall EA, Fleischmann RM, Bulpitt K, Weaver AL, Keystone EC, Furst DE, Mease PJ, Arkfeld DG, Garrison L, Burge DJ, Blosch CM, Lange ML, Weinblatt ME 1999. Etarnecept therapy in rheumatoid arthritis, A randomized, controlled trial. Ann Intern Med 130: 478-486

Newbould BB 1963. Chemotherapy of arthritis induced in rats by Mycobacterial adjuvant. Brit J Clin Pharmacol 21: 127-136.

Pélissler Y, Marion C, Kone D, Lamaty G, Menut C, Besslere JM 1994. Volatile components of Annona muricata L. $J$ Essent Oil Res 6: 411-414.

Rajkapoor B, Ravichandra V, Gobinath M, Anbu J, Harikrishnan N, Sumithra M, Sankari M, Venugopal $\mathrm{R}$, Sakthisekaran D 2007. Effect of Bauhinia variegate on Complete Freund's Adjuvant induced arthritis in rats. J Pharmacol Toxicol 2: 465-472.

Ratheesh M, Helen A 2007. Anti-inflammatory activity of Ruta graveolens Linn on carrageenan-induced paw oedema in rats: Afr J Biotechnol 6: 1209-1211.

Roslida AH,. Tay CE, Zuraini A, Chan PF 2010. Antiinflammatory and antinociceptive activities of the ethanolic extract of Annona muricata leaf. $J$ Nat Remedies 10: 97-104.

Roslida AH, Chan PF, Zuraini A, Khairi HM 2012. Antinociceptive and anti-ulcerogenic activities of the ethanolic extract of Annona muricata leaf. Rev Bras Farmacogn 22: 630-641.

Santos AF, Sant'Ana AEG 2001. Molluscicidal properties of some species of Annona. Phytomedicine 8: 115-120.

Serafini M, Peluso I, Ragguzzini A 2010. Flavonoids as antiinflammatory agents. P Nutr Soc 69: 273-278.

Singh S, Majumdar DK 1996. Effect of fixed oil of Ocimum sanctum against experimentally induced arthritis and joint edema in laboratory animals. Int $J$ Pharmacogn 34: 218-222.

Singh B, Bani S, Gupta DK, Chandan BK, Kaul A 2003. Antiinflammatory activity of 'TAF' an active fraction from the plant Barleria prionitis Linn. J Ethnopharmacol 85: 187-93.

Tang X, Lin Z, Cai W, Chen N, Shen L 1984. Anti-inflammatory effect of 3-acethylaconitine. Acta Pharmacol Sin 5: 85-89.

Tapas AR, Sakarkar DM, Kakde RB 2008. Flavonoids as nutraceuticals: A review. Trop J Pharm Res 7: 10891099.

Tormo JR, Royo I, Gallardo T, Zafra-Polo MC, Hernandez P, Cortes D, Pelaez. F 2003. In vitro-antitumor structure activity relationships of threo/trans/three monotetrahydrofuranic acetogenins: correlations with their inhibition of mitochondrial complex 1. Oncol Res 14: $147-54$.

Tripathy S, Sahoo SP, Pradhan D, Sahoo S, Satapathy
DK 2009. Evaluation of anti-arthritic potential of Hybanthus enneaspermus. Afr J Pharm Pharmacol 3: 614-617.

Tunón MJ, Garcia_Mediavilla MV, Sanchez-Campos S, Gonzalez-Gallego J 2009. Potential of flavonoids as antiinflammatory agents: modulation of pro-inflammatory gene expressiona and signal transduction pathways. Curr Drug Metab 10: 256-271.

Ward JR, Cloud RS 1965 Comparative effect of antirheumatic drugs on adjuvant induced polyarthritis in rats. $J$ Pharmacol Exp Ther 152: 116-121.

Wu FE, Zeng L, Gu ZM, Zhao GX, Zhang Y, Schwedler JT, McLaughlin JL, Sastrodihardjo S 1995a. Muricatocins $\mathrm{A}$ and $\mathrm{B}$, two new bioactive monotetrahydrofuran Annonaceous acetogenins from the leaves of Annona muricata. J Nat Prod 58: 902-908.

Wu FE, Gu ZM, Zeng L, Zhao GX, Zhang Y, McLaughlin JL, Sastrodihardjo S 1995b. Two new cytotoxic monotetrahydrofuran Annonaceous acetogenins, annomuricins $\mathrm{A}$ and $\mathrm{B}$, from the leaves of Annona muricata. J Nat Prod 58: 830-836.

Wu FE, Zeng L, Gu ZM, Zhao GX, Zhang Y, Schwedler JT, McLaughlin JL, Sastrodihardjo S 1995c. New bioactive monotetrahydrofuran Annonaceous acetogenins, annomuricin $\mathrm{C}$ and muricatocin $\mathrm{C}$, from the leaves of Annona muricata. J Nat Prod 58: 909-915.

Wu FE, Zhao GX, Zeng L, Zhang Y, Schwedler JT, McLaughlin JL, Sastrodihardjo S 1995d. Additional bioactive acetogenins, annomutacin and (2,4-trans and $c i s$ )-10R-annonacin-A-ones, from the leaves of Annona muricata. J Nat Prod 58: 1430-1437.

Yuan SS, Chang HL, Chen HW, Yeh YT, Kao YH, Lin KH, $\mathrm{Su}$ JH 2003. Annonacin, a mono-tetrahydrofuran acetogenin, arrests cancer cells at the G1 phase and causes cytotoxicity in a Bax- and caspase-3-related pathway. Life Sci 72: 2853-2861.

Zaninir JC, Medeiros YS, Cruz AB, Yunes RRA, Calixto JB 1992. Action of compounds from Mandevilla velutina on croton oil-induced ear oedema in mice. A comparative study with steroidal and nonsteroidal antiinflammatory drugs. Phytother Res 6: 1-5.

Zeng L, Wu FE, Oberlies NH, McLaughlin JL, Sastrodihardjo S 1996. Five new monotetrahydrofuran ring acetogenins from the leaves of Annona muricata. $J$ Nat Prod 59: 1035-1042.

\section{*Correspondence}

\section{Roslida AH}

Department of Biomedical Sciences, Faculty of Medicine \& Health Sciences, Universiti Putra 43400 Serdang, Selangor, Malaysia

roslida@medic.upm.edu.my

Tel. +60389472341

Fax: +60 389436178 